Ethiopian Journal of Environmental Studies \& Management 9(3): 326 - 338, 2016.

ISSN:1998-0507

doi: http://dx.doi.org/10.4314/ejesm.v9i3.7

Submitted: January 08, 2016

Accepted: May 06, 2016

\title{
CLIMATE CHANGE AND ADAPTATION STRATEGIES TO WATER RESOURCES IN SOME PARTS OF SUDANO- SAHELIAN ZONE OF NIGERIA
}

\author{
OJOYE, S., ${ }^{*}$ *SLYMAN, A.0. ${ }^{2}$ AND YAHAYA, T.I. ${ }^{1}$ \\ ${ }^{1}$ Department of Geography Federal University of Technology, Minna, Nigeria \\ ${ }^{2}$ Urban and Regional Planning Department, Federal University of Technology, Minna, \\ Nigeria
}

\begin{abstract}
This study examines the impact of climate change on water resources in some parts of the Sudano-Sahelian zone of Nigeria. Climatological data of rainfall amount, temperature and evaporation from rivers and lakes in the zone were collected from Nigeria Meteorological Agency(NIMET), Lagos and Nigeria Hydrological Services in Kaduna respectively while data of river discharge and lake levels were also collected from Nigeria Hydrological Services. The Standardized anomaly index was used to test for fluctuations in rainfall. Temperature, runoff and water level in lakes, the trend analysis was used to examine the trends in these variables. Three hundred and sixty copies of structured questionnaires were used to examine the adaptation to water resource including water for domestic use, agricultural use, and water available in rivers. The study revealed that there was an upward trend in rainfall and an increase in river discharge amount between 1990 and 2013 which accounts for flood episodes in the zone. Some of the adaptation options put in place in the zone are; dredging of rivers, improved irrigation scheme, restrictions of development along flood plains among others. The study therefore recommends a review of operational rules on dams and proper initiation of flood control measures.
\end{abstract}

Key Words: Adaptation, Climate Change, Flood, Hydrologic Cycle, Sudano-Sahelian

\section{Introduction}

IPCC (2007) Fourth Assessment Report (AR4) gave the most acceptable definition of climate change, which states that "climate change is a change in the state of the climate that can be identified (e.g. by using statistical tests) by changes in the mean and/or the variability of its properties, and that persists for an extended period typically decades or longer". Climate change is different from the generally known terms like climatic fluctuations or climatic variability.
Climate fluctuation or variability refers to variations in the mean state and other statistics (such as standard deviations, the occurrence of extremes, etc) of the climate on all spatial and temporal scales beyond that of individual weather events. Like climate change, variability may be due to; natural internal processes within the climate system (internal variability), or variations in natural or anthropogenic external forces (external variability). The most crucial things about the concept of climate change is not only the time 
periods involved but also the degree of variability that the change is subjected to as well as the duration and impact of such variability on man and the ecosystem.

The causes of climate change are both natural and anthropogenic. For the past few decades, anthropogenic factors likes urbanization, deforestation, population explosion, Industrialization and the release of greenhouse gases are the major contributing factors to the depletion of the ozone layer and its associated global warming and climate change (Odjugo, 2007). There have been growing awareness that the earth's climate is changing at an alarming rate and the Fourth Assessment Report of the Intergovernmental Panel on Climate Change (IPCC) affirms that climate change is no longer in doubt but is now unequivocally apparent based on evidence from scientific observations of increases in global average air and ocean temperatures (IPCC, 2007). Although extreme violent weather has occurred throughout history, recent upsurge in climate related hazards is confirming the argument for global warming and climate change (Nwafor, 2006).

Available evidences show that climate change will be global, likewise its impacts, but the biting effects will be felt more by the developing countries especially those in Africa due to their low level of coping capabilities (Jagtap, 2007). Nigeria is one of such developing countries. Researchers have shown that Nigeria is already being plagued with diverse ecological problems, which have been directly linked to the on-going climate change (Ikhile, 2007). These studies focused more on climatic impacts. Studies that address climate trends in Nigeria cover either short period or small area (Afiesimama, 1999; Anyadike 1992a; 1992b; Clerk 2002; Nkeiruka and Apagu, 2005; Olaniran 2002; Odjugo, 2005; Nnodu et al., 2007), whereas Singer and Avery (2007) revealed that it takes at least a century of weather data to evaluate climate trend for a reasonable conclusion to be drawn. There is therefore the need to examine the climatic pattern of Nigeria over a long time as also suggested by Nwafor (2006) so as to capture the long term changes in the climate of Nigeria with respect to water resources. It is on this premise that this study examined the climatic pattern of the Sudano-Sahelian Ecological zone of Nigeria between 1960 and 2013 (54 years), using rainfall, and temperature data. Based on these data, the question as to whether there are enough changes in the spatiotemporal pattern of rainfall and temperature over Nigeria to support the concept of regional climate change is answered; a larger area of the country is also covered; most of the earlier study did not focused on water resources even with evidences that there are challenges of water scarcity that is widespread in the zone.

The aim of this study is to examine climate change and adaptation options to water resources in some parts of the Sudano-Sahelian ecological zone of Nigeria with a view of identifying the best option for the zone. To achieve this aim the following are the specific objectives; to examine the changes in the rainfall and temperature patterns over a period of fifty -four years (1960-2013); to assess the vulnerability of the zone to shortage in water that affects human use and also to look into the adaptation strategies to curb the shortages experienced in the area. 


\section{Study Area}

The Sudano-Sahelian ecological zone (SSEZ) of Nigeria is a large ecological zone that occupies almost one-third of the total land mass of the country. The area lies in the north between longitudes $4^{\circ}$ and $14^{\circ} \mathrm{E}$, and latitudes $10^{\circ}$ and $14^{\circ} \mathrm{N}$. It stretches from the Sokoto plains through the northern section of the high plains of hausaland to the Chad basin (Figure 1).

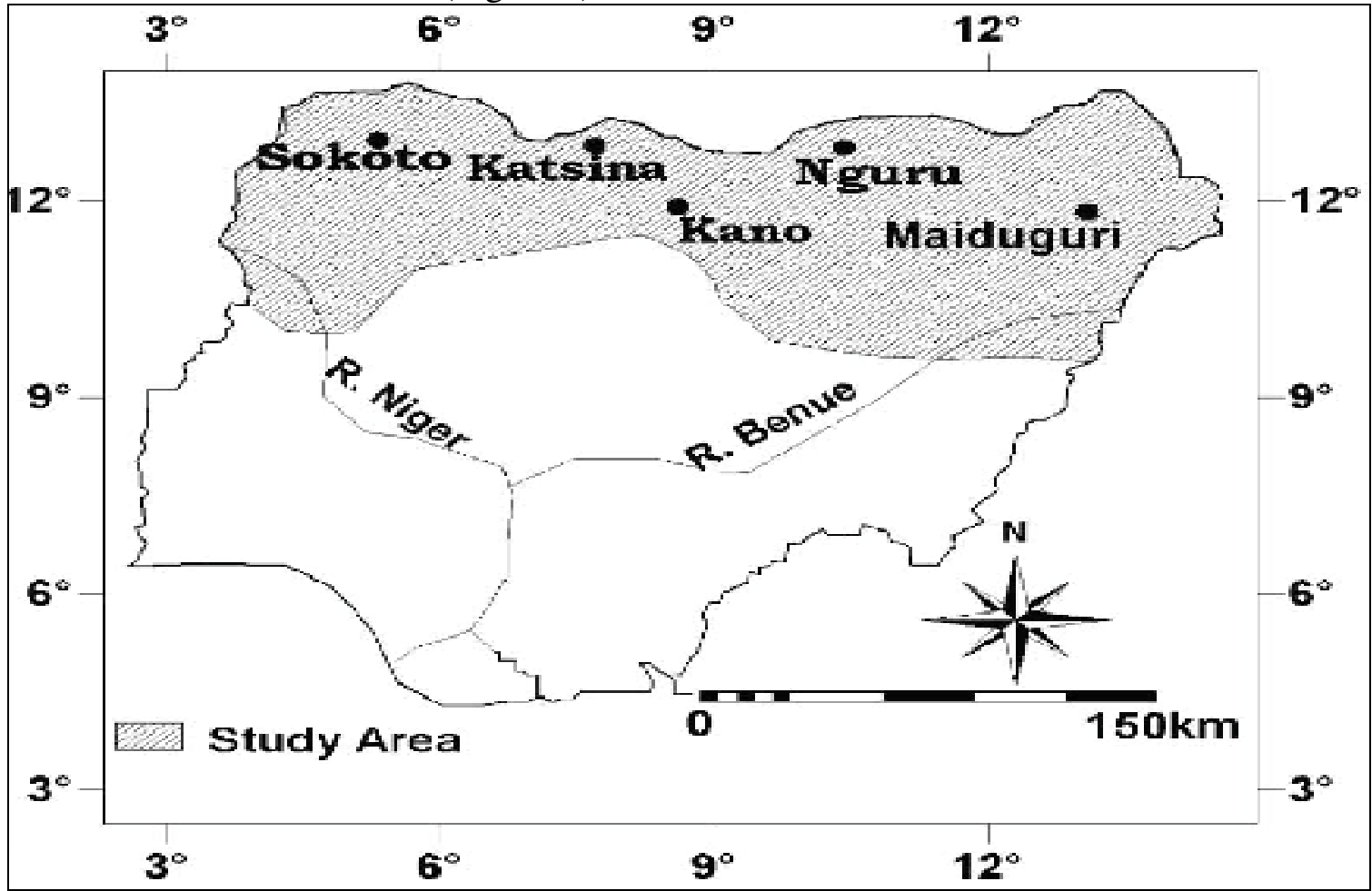

Figure 1: Map of Nigeria showing the Sudano-Sahelian ecological zone of Nigeria

The climate of the Sudano-Sahelian ecological zone of Nigeria is dominated by the influence of three major meteorological features, namely; the Tropical Maritime (mT) air-mass, the Tropical Continental (cT) air-mass, and the equatorial easterlies (Odekunle et al, 2008). The first two air- masses (mT and cT) meet along a slanting surface called the inter-tropical discontinuity (ITD); the equatorial easterlies are rather erratic and relatively cool air masses from the east in the upper troposphere along the ITD. The
This ecological zone houses onequarter of the Nigerian population, supports about $90 \%$ of the cattle population, about two-thirds of the goats and sheep, and almost all the donkeys, camels and horses found in the country. Cereals, cow peas, groundnut and cotton are the main crops grown in the region (Odekunle et al., 2008). 
Climate Change and Adaptation Strategies to Water Resources.................0JOYE et al.

influence the amount and seasonal distribution of rainfall over the region.

Temperature in the region is high throughout the year with a mean minimum value of about $23^{\circ} \mathrm{C}$ and mean maximum of about $34^{\circ} \mathrm{C}$ (Ojoye, 2008). In areas of high altitudes (Jos plateau $(606 \mathrm{~m})$ lower temperature are experienced during the cold, dry season of harmattan weather. In the rainy season, temperature are fairly steady because cloudiness and humidity prevent back radiation, thus the diurnal range of temperature is relatively small it is about $2{ }^{\circ} \mathrm{C}$ (Oyebande 2000). In the dry season the much back radiation is witnessed in the night and it tend to lower night temperature values. Thus a high diurnal range of temperature sometimes as high as $12^{\circ} \mathrm{C}$ is observable.

\section{Materials and Methods}

Data for this study were collected from both primary and secondary sources. The climate data include data on rainfall and temperature which was collected from Nigeria Meteorological Agency (NIMET) office in Oshodi, Lagos. The hydrologic data include runoff data for selected river basins in the study area and Lake Yield which was collected from National hydrological Centre, Mando, Kaduna State. The socioeconomic data include information from structured questionnaire and group discussions. The administration of questionnaires and oral interview was adopted to substantiate the information that was received from the secondary sources. Table 1.0 shows the various data points selected for the study.
Table 1: The selected stations for the study

\begin{tabular}{lll}
\hline S/N & States & Met. Stations. \\
\hline 1 & Jigawa & Dutse \\
2 & Kano & Kano \\
3 & Katsina & Katsina \\
4 & Kebbi & Yelwa \\
5 & Sokoto & Sokoto \\
6 & Yobe & Nguru \\
7 & Borno & Maiduguri \\
\hline
\end{tabular}

Nigerian Meteorological Agency (2014)

Rainfall records for seven selected stations shown (shown in Figure 1) for the period 1960-2013 were collected. Annual rainfall totals were collected and from these wet and dry seasons' rainfalls, rain days; daily rainfalls of different sizes were generated. These rainfall attributes are of great practical importance to water resources both surface and underground.

The standardized rainfall anomaly index (SRAI) adapted from Ojoye, (2012) was used to examine the changes that has taken place in the rainfall distribution over the period $1960-2013$. This index has been found effective for rainfall variability in Niger basin area and Sudano Sahelian Ecological Zone by Babatolu (1998), and Ojoye (2012) respectively. The SRAI were calculated for individual station using the following equation

$\mathrm{X}_{\mathrm{ij}}=\frac{1}{N j} \Sigma_{\mathrm{I}}^{\mathrm{NT}}(\mathrm{rij}-\mathrm{ri}) \sigma_{\mathrm{i}}$

Where

$\mathrm{X}_{\mathrm{ij}} \quad=$ rainfall departure for $\mathrm{jth}$ year

rij $=$ the year's rainfall total at station $\mathrm{i}$

$r_{i}=$ the mean of station i's totals for the base period

$\sigma \quad=$ the standard deviation of station I's totals for the base period

$\mathrm{N}_{\mathrm{j}}=$ is the number of stations with complete records in year $\mathrm{j}$. 
Multiple Regressions Statistical model was also used to assess the relationships between rainfall, and temperature on the water resources in the study area. The multiple regression equation is given as:

$Y=a_{1}+b_{1} x_{1}+b_{2} x_{2}+b_{3} x_{3} \ldots+b_{n} x_{n----}(2)$

Where $\mathrm{Y}=$ Water resources factors such as water level in dams, borehole and well yield etc.

$\mathrm{X}_{1}=$ Rainfall, $\mathrm{X}_{2}=$ Temperature,

$a_{1}, b_{1}, b_{2} \ldots b_{n}$ are constants

The use of questionnaire was employed in the gathering of socioeconomic data. The questionnaire were distributed among the water managers, the community leaders and all other set of individuals that are connected with and affected by the management of water resources in the zones. Each of the study area was sampled based on their closeness to the basin. Simple

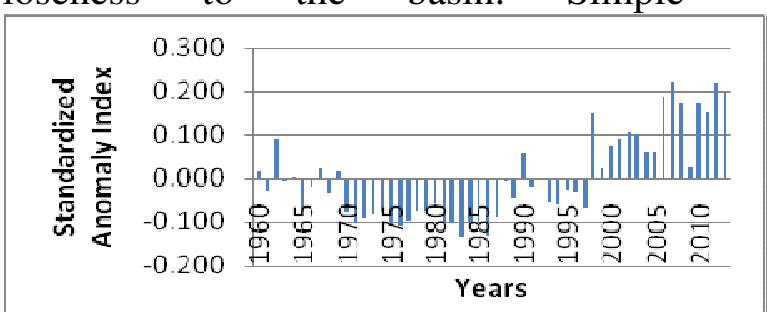

Figure 2a: Annual Rainfall anomaly in Kano

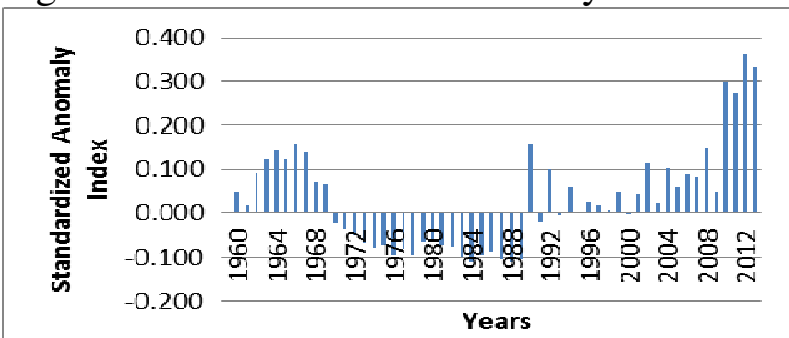

Figure 2c: Annual Rainfall anomaly in Sokoto

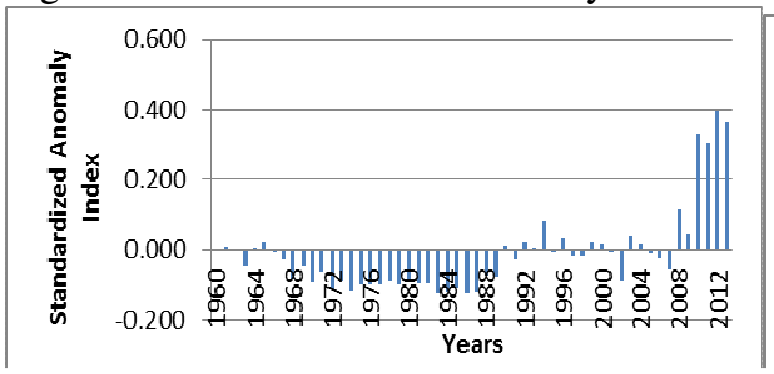

Figure 2e: Annual Rainfall anomaly in Dutse percentages and graphs were used to analyze the questionnaires. The sampling method used in the administration of the questionnaire is purposeful sampling.

\section{Results and Discussion}

Anomalies in Annual Rainfall in Sudano-Sahelian Ecological Zone of Nigeria

During the 54 years under study (1960 to 2013), yearly rainfall at various stations fluctuated markedly around their long-term means. The graphs in figure 2 (a to g) reveal distinct periods of short term and long term rainfall fluctuations with the period 1970s and 1980s recording unparalleled long run of dry years (below long term average rainfall) at many of the stations with this more pronounced in Nguru, Sokoto, Kano and Maiduguri.

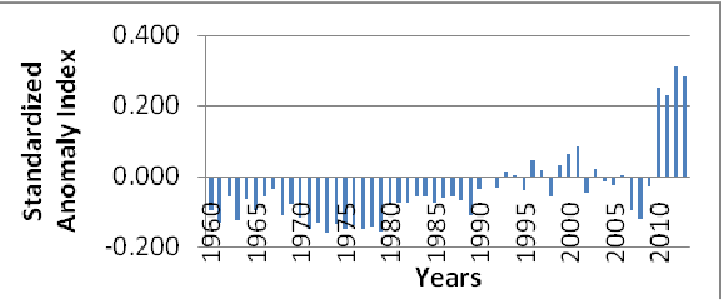

Figure 2b: Annual Rainfall anomaly in Nguru

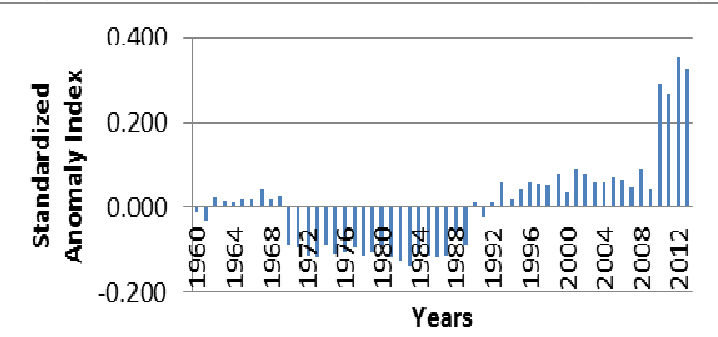

Figure 2d: Annual Rainfall anomaly in Yelwa

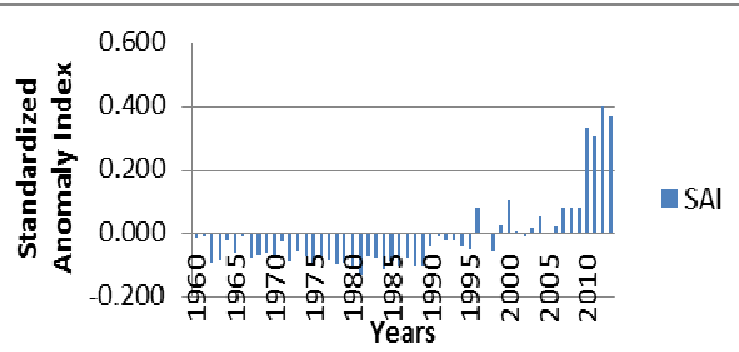

Figure 2f: Annual Rainfall anomaly in Maiduguri 
Climate Change and Adaptation Strategies to Water Resources.................JOYE et al.

Most of the seven rainfall series selected for the study showed that the period 1960 to 2013 contains four distinct periods when rainfall exhibited trends of particular type was most persistent. The first is manifested in below long term average which occurred before the wet years of 1960s. This period varies in severity and length over the region being markedly longest and severest in most of the stations with the period 1970 to 1987 receiving over 5 percent below the longterm average. However there were occasional respites such as in 1990 (for Kano), 1996 and 2001 for Nguru, 1962 to 1968 for Sokoto, 1995 for Dutse, 1990, 1991 and 1992 for Katsina. At Kano the entire 1970s and 1980s were dry years with most of the years below the long term average. 1990s and 2000 to 2009 were wet years with most of the years exhibiting more than 20 percent above the long- term mean.

Another feature of figure 2 (a to g) is the extended period of below long-term average rainfall particularly since 1970 at most of the stations and which has intensified since the $1980 \mathrm{~s}$ at all the stations. In general the long dry phase in the SSEZ of Nigeria beginning since 1970 contained the severe drought of 1972/73 and those of 1980s which have been widely supported in literatures. Apparently, the drought of 1972/73 varied greatly in spatial extent and in magnitude over the study area and was clearly less severe compared with the drought of the 1980s. In the 1970s, rainfall over the study area was 2.7 to 10 percent below the long-term average while that of the $1980 \mathrm{~s}$ was 5 to 18.5 percent below the mean (Figure 2).

Anomalies in Annual Temperature in Sudano Sahelian Ecological Zone of Nigeria

The results in Figures 3 (a-g) reveals that for the base period 1960-2013 there is a significant upward trend in almost all the stations considered with a very high value(0.83) in Maiduguri which reveals that the stations have been warming from 1960 to 2013. This conclusion is strengthened by the results of other study (Adesina, 2008, Dami, 2008, Ojoye, 2012). When the trend was also considered on a climatological year basis, the results also confirm the earlier increasing trend as in 1960-2013 base periods. The trend is more significant in the base period 1960-1989(the decades that is regarded as the driest so far in the zone) due to the recurring drought at this period.

The general temporal variation of temperature anomalies of a particular type were most marked. The pre-drought years of $1960 \mathrm{~s}$, the prolonged and persistent drought of the 1970s and 1980s and the wet period of 1990 to 2013. The analyses also show that 1960 s is wetter than the 1970s and 1980s, the study showed that 1972 and 1973 with many years in 1980s drier than other years in the same decade. 
Ethiopian Journal of Environmental Studies and Management Vol. 9 no.32016

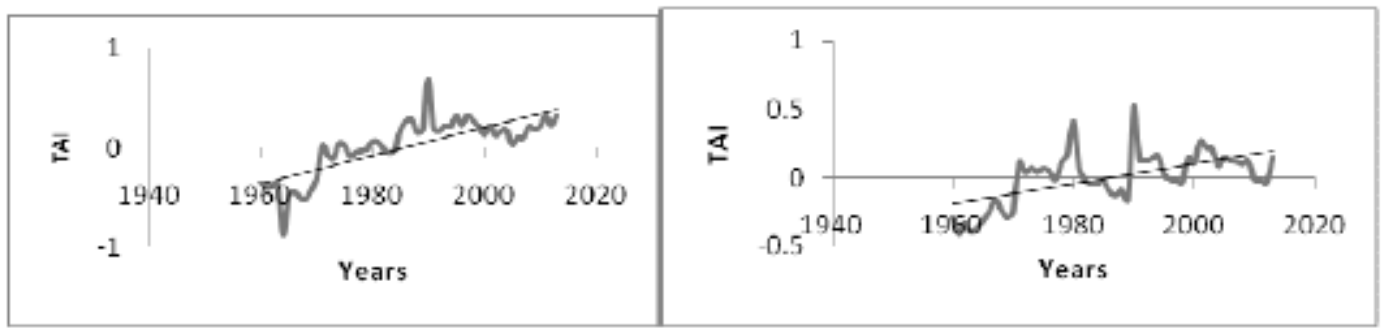

Figure 3a. Temperature anomaly for Kano

Figure 3b. Temperature anomaly for Nguru
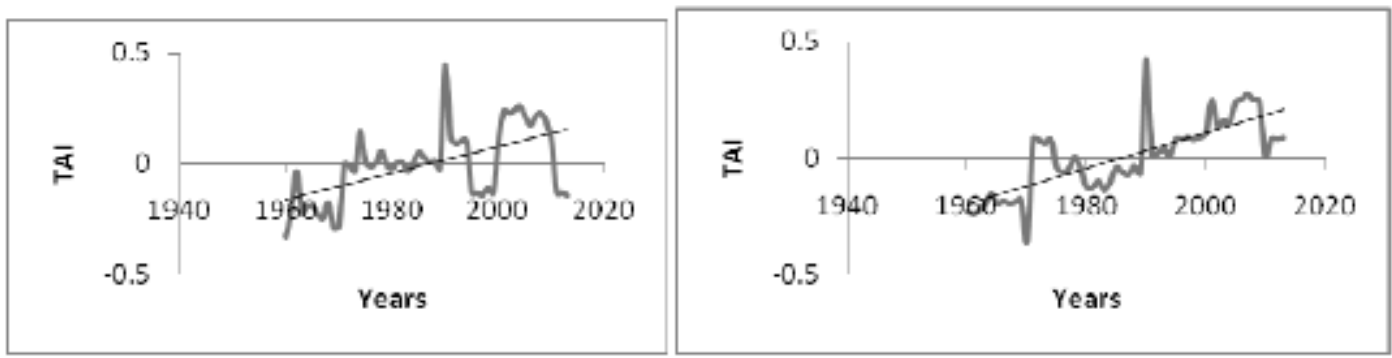

Figure 3c. Temperature anomaly for Sokoto

Figure 3d. Temperature anomaly for Yelwa
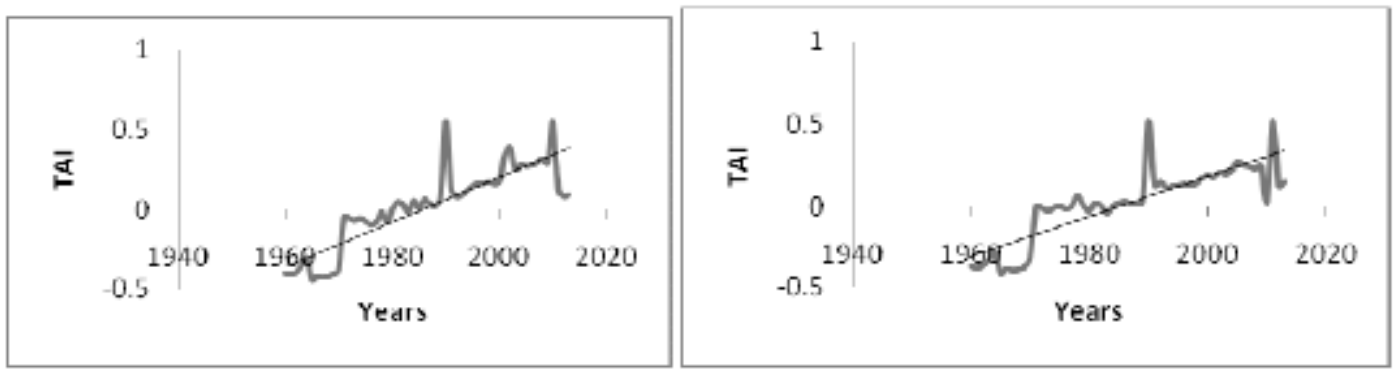

Figure 3e. Temperature anomaly for Maiduguri Figure 3f. Temperature anomaly for Dutse

\section{Fluctuations in Annual Runoff in the SSEZ of Nigeria}

The fluctuations in runoff in the Sudano-Sahelian Ecological zone of Nigeria can be clearly revealed through the graphs in Figures 4 (a-g). Sokoto (Fig 4a) runoff series during the period 19682008 contains several phases of low and high water. They differ in duration and degree of deviation of runoff from the average for the whole period. The duration of persistently low and high water phases does not exceed 10 years. In general, four phases of low and high water can be observed. Above average runoff occurred during the pre 1970s and 1987- 90 while below average runoff was observed during 1970-1975 and 19801990 periods. The below average runoff which commenced in 1970 is less severe compared to the 1980s. The positive runoff anomalies are stronger than the negative ones. 
Climate Change and Adaptation Strategies to Water Resources.................JOYE et al.

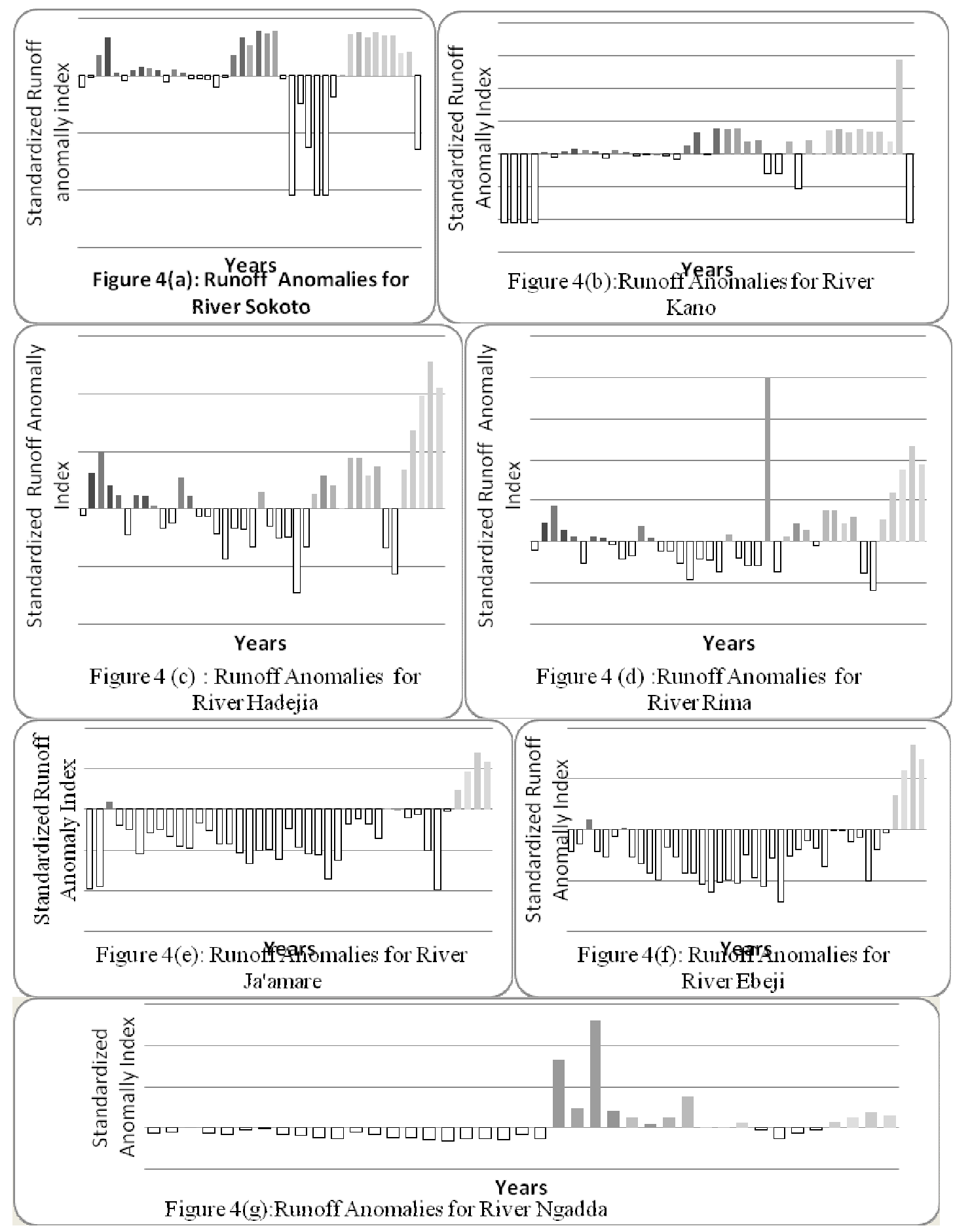

A detailed analysis of the runoff series shows two synchronous fluctuations over the study period. A higher than average runoff occurred in pre-1970s and post-2000. The lower than average runoff was most pronounced in
Ja'amare River with virtually all the years from 1968-2004 found to record below average runoff. These period of below average runoff period centre sharply with the above average runoff period in the late 1960s and late 1990s in 
most of the series. The synchronous fluctuations in runoff in these rivers was also observed by Faure and Gac (1981), Babatolu (1998) and Dami(2008) in the African Sahel, Niger River basin area and Northern Nigerian rivers respectively.

Deviation of annual total runoff from the mean for this period considered is generally large and within the range of 22.9 to 1.06 percent in river Ebeji, -8.4 to 13.8 percent in river Sokoto. This result show that the amplitude of oscillation of the annual runoff increases inversely with the basin size being greatest in the smaller basin (Ngadda). This is in agreement with the observation of Scheake and Kaczmarek (1985 of Babatolu, 1998) that for small catchments, the variability of surface flow is amplified, because runoff is a residual of precipitation and evaporation.

\section{Fluctuations in Water level in Lakes in} the SSEZ of Nigeria

For the purpose of this study, the major lakes in the study area with consistent and long period of records were selected. Most of the flow in the Hadejia River System $(\approx 80 \%)$ is controlled by Tiga dam with storage capacity of about $1492 \times 10^{6} \mathrm{~m}^{3}$ and Challawa dam $\left(972 \times 10^{6} \mathrm{~m}^{3}\right)$. Coupled with other factors the following lakes were considered

\section{i. Tiga \\ ii. Challawa \\ iii. Nigeria portion of Lake Chad}

The three lakes mentioned above have more than twenty years of consistent daily water level data. The annual water level series contain few periods of persistently low and high water levels. The lakes water levels series contains two contrasting periods, higher than average water level in the lakes occurred in the pre-1970s and post 2000 while lower than average water level is apparent in the 1970s to 1990s.

The variations in water level in these lakes bear a remarkable relation with rainfall change in the study area. The explanation to this is not far-fetched owing to the fact that the region is ravaged by lower than normal rainfall at these periods. This implies that climate change causes water resources shortage in the region. It may also be attributed to the fact that agricultural development, rapid urbanization and industrialization growth are increasingly modifying the natural runoff process and exerting growing demands on the water supply. Goes, (2001) have shown that Tiga and Challawa dams' level correlate closely with rainfall over a wide area. Goudie (1977) also found that response to the relatively dry phase of the 1920s and the following decades Lake Malawi reached a minimum around 1927-1929 while Lake Victoria's lowest level was reached in 1922. UNEP (2004) reported that from 1967-1992/93, Lake Chad was reduced in area by 65 percent. All these authors' findings were attributed to the lakes response to rainfall decline.

Stage Response to Long-Term Changes in Rainfall conditions in the SSEZ of Nigeria

Correlation analyses were carried out to determine and explain the nature and magnitude of the relationships between the parameters of rainfall and stage. The results are presented in table 2 . The results show that there is a positive significant relationship between the annual rainfall and mean stage in all the selected sub-basins tracking the results for runoff. This suggests that large proportion of reduction in the mean stage can be explained by the decline in annual rainfall in the zone. The results in Table 2 
Climate Change and Adaptation Strategies to Water Resources.................0JOYE et al.

also show that there is generally insignificant but positive relationship between rainfall of different attributes and mean stage of streams. The table also shows that there is positive significant correlation between wet season rainfall and mean stage in all the rivers of the selected sub-basins. This shows that decline in wet season rainfall is an important contributory factor to the decline in the means stage in the SSEZ of Nigeria.

The results in table 2 show a positive significant relationship between heavy rainfall and mean stage of rivers Hadejia,
Rima and Ngadda, one of the biggest rivers in the study area and positive but less significant in the case of Ebeji. These results suggest that big streams are more responsive to climate change than the small ones. This corroborates the findings of Novaky et al (1985) cited in Babatolu, 1998, Ojoye (2012) that for small catchment or low flows the variability of surface flow is amplified, because runoff is a residual of precipitation and evaporation and its variability surpasses the variability of precipitation particularly in areas with little runoff.

Table 2: Rainfall-Stage correlation in the SSEZ

\begin{tabular}{lllllll}
\hline Rivers & $\begin{array}{l}\text { Annual } \\
\text { rainfall }\end{array}$ & $\begin{array}{l}\text { Dry season } \\
\text { Rainfall }\end{array}$ & $\begin{array}{l}\text { Wet season } \\
\text { Rainfall }\end{array}$ & $\begin{array}{l}\text { Heavy } \\
\text { Rainfall }\end{array}$ & $\begin{array}{l}\text { Annual } \\
\text { Rain days }\end{array}$ & $\begin{array}{l}\text { Rain days } \\
\text { of heavy } \\
\text { rainfall }\end{array}$ \\
\hline Sokoto & 0.52 & 0.32 & 0.51 & 0.45 & 0.69 & 0.54 \\
Kano & 0.64 & 0.34 & 0.62 & 0.53 & 0.63 & 0.62 \\
Hadejia & 0.72 & 0.35 & 0.70 & 0.62 & 0.60 & 0.57 \\
Rima & 0.68 & 0.40 & 0.65 & 0.61 & 0.62 & 0.64 \\
Ja'amare & 0.47 & 0.25 & 0.51 & 0.51 & 0.53 & 0.53 \\
Ebeji & 0.62 & 0.47 & 0.48 & 0.43 & 0.41 & 0.50 \\
Ngadda & 0.78 & 0.53 & 0.64 & 0.81 & 0.75 & 0.68 \\
\hline
\end{tabular}

Response of Water Level in Lakes to Long-Term Changes in Rainfall Conditions in the SSEZ

In the absence of monitored natural lakes, artificial lakes on the selected rivers were selected for study. Fluctuations of water level in lakes such as these are mainly caused by runoff of the rivers on which they are constructed which is in turn influenced by rainfall. The results of the correlation analysis between the rainfall parameters and the water level in lakes in the SSEZ are presented in Table 3.

Table 3: Correlation between Rainfall and Water Level in Lakes.

\begin{tabular}{lllllll}
\hline Lakes & $\begin{array}{l}\text { Annual } \\
\text { rainfall }\end{array}$ & $\begin{array}{l}\text { Dry season } \\
\text { Rainfall }\end{array}$ & $\begin{array}{l}\text { Wet season } \\
\text { Rainfall }\end{array}$ & $\begin{array}{l}\text { Heavy } \\
\text { Rainfall }\end{array}$ & $\begin{array}{l}\text { Annual } \\
\text { Rain days }\end{array}$ & $\begin{array}{l}\text { Rain days of } \\
\text { heavy } \\
\text { rainfall }\end{array}$ \\
\hline Tiga & 0.65 & 0.48 & 0.30 & 0.64 & 0.63 & 0.43 \\
Challawa & 0.75 & 0.52 & 0.50 & 0.58 & 0.67 & 0.65 \\
Lake Chad & 0.42 & 0.40 & 0.30 & 0.40 & 0.42 & 0.48 \\
\hline
\end{tabular}


The results show that there is a positive relationship between all the rainfall attributes for Sokoto-Rima lakes with only insignificant but positive values in the wet-season rainfall. This is due to the fact that during the wet season the water from the lakes is diverted for other domestic uses. This also may be due to the large-scale human activity on the lakes. The Hadejia-Ja'amare lake show a positive correlation between the water level and all the rainfall attributes in the selected period. When all the rainfall attributes are correlated with water level in the Nigerian portion of lake Chad, it was observed that there is a positive but insignificant correlation, an indication that this lake is seriously been affected by climate change. This implies that the reduction in the water level in the lake is attributable to shortage of rainfall; a factor that has been traced to the changing climate. It was also reveals that there is a variation in the the lake level at different parts of the zone, an indication that the changes is spatially distributed. Urbanization and industrial development increase water demand which may result in reduction in the surface water supply whilst increase in farming activity and deforestation are also responsible for the decrease in surface water supply.

\section{Adaptation Strategies to Water Resources Management}

This study has shown that large fluctuations in rainfall are inherent characteristics of the rainfall regime of the SSEZ. The period of study was characterized by long persistent wet and dry conditions. The wet conditions were seen in those periods when rainfall amount was found to be above the baseperiod mean and dry periods are characterized by a lower than normal rainfall which make the region vulnerable to extreme weather events expressed in floods and drought respectively. Flood events may increase during the period of persistent wet conditions and even occasionally during the dry years in all the selected sub-basins. The management options for minimizing the vulnerability to flood hazard include: supply management options, demand management options, watershed management options and nonmanagement options. These options are fundamental to the prevention and management of possible flood hazards with pervasive impact on human life and the environment.

Supply management options used in the study involve the modifications of the hydrology of the basin to maintain the reliability of water supplies and provide protection from drought. Under these options, reservoirs are constructed on important streams to provide protection from floods. Such reservoirs have been found to regulate runoff by altering both spatial and temporal distribution of water.

Demand management options involve maintaining of water supply reliability through increased flexibility by adjusting water use to match changes in water supply. Adaptive measure in this category is restriction of development on the flood plain.

Watershed management used in the study area include expansion of forest by planting of trees which have attenuating effect on flood by reducing the rate of siltation of stream channels and runoff. In the study area, the cheapest source of fuel for cooking is wood which in turn have an adverse effect on the climate of the area due to deforestation. 
Climate Change and Adaptation Strategies to Water Resources.................JOYE et al.

\section{Conclusion and Recommendations}

Climate change and adaptation to water resources has been examined in this study. Historical data of precipitation characteristics have been used to establish a change in climate in the Sudano-Sahelian Ecological Zone of Nigeria from 1960-2013. It is evident from the study that the drought of 1972/73 in the Northern part of Nigeria actually have its toll on the climate of the Sudano-Sahelian ecological zone as all the station in the region showed a below normal rainfall in 1970-1980 and this trend persisted till 1980s which is even more intense than what was observed in the 1970s. This trend in climate has an adverse effect on the water resources in the area in the sense that the decrease in rainfall in the zone has resulted in decrease in river discharge and in water level in lakes. It was also revealed that this decrease have implications for irrigated agriculture, municipal and industrial water supply, the results also revealed that improper management of the flood plain in some of the stations have been responsible for the recent flood that is now an everyday event in the zone. A broad array of adaptive mechanisms that will help reduce, ameliorate or mitigate the ravaging effect of climate change on water resources in the area have been advanced. It is also pertinent to note that unless the people of the area change their attitude towards improper management of the little water resources available in the area and also try to reduce their human activities that bring forth faster rate of climate change, the zone will always lack adequate supply of the needed water resources.

\section{References}

Babatolu, J.S. (1998). Climate Change and its Implications for Water Supply in the Niger River Basin Development Authority Area of Nigeria". Unpublished Ph.D Thesis, Department of Geography, University of Ilorin, Ilorin.

Goes, B.J.M. (2001). Regional Management of Water Resources; Proceedings of a Symposium held during the sixth IAHS Scientific Assembly at Maastricht, The Netherlands). IAHS Publ. no. 268, 2001.

Goudie, A. (1977). Environmental Change, Oxford, Clarendon Press. 148-149pp

IPCC. (2007). Fourth Assessment Report. Intergovernmental Panel on Climate Change Secretariat. Geneva, Switzerland. http://www.ipcc.ch

IPCC. (2001). Climate Change 2001: The Scientific Basis. Contribution of Working Group I to the Third Assessment Report of the Intergovernmental Panel on Climate Change (Houghton, J.T., Y. Ding, D.J.Griggs, N. Noguer, P.J. van der Linden, X. Dai, K. Maskell and C.A. Johnson (eds). Cambridge University Press, Cambridge, United Kingdom and New York, NY, USA.

Katz, R.W., and Glantz, J.K. (1986). Techniques for Estimating Uncertainty in Climate Change Scenarios and Impact Studies. Climate Research, 20: 167-185

Odekunle, O.T., Andrew, O., Aremu, O.S. (2008). Towards a Wetter Sudano-Sahelian Ecological Zone in the Twenty-First Century Nigeria. Journal of Weather and the Environment, 63(3): 46-51. 
Ojoye, S. (2007). Rainfall Variability and its Influence on Maize Production in Northern Nigeria. Conference Proceedings, School of Science and Science Education, Federal University of Technology, Minna. Nigeria.

Ojoye, S. (2008). Climate Change and Crop Production, Journal of Science and Technology, Federal University of Technology, Minna. Nigeria.

Ojoye, S. (2012). Climate Change Impact on Water Resources and Adaptation Strategies in Sudano Sahelian Ecological Zone. An unpublished Ph.D thesis, Department of Geography and Environmental Management, University of Ilorin, Ilorin. 